\title{
Response to treatment by multidrug regimens in the THELEP controlled clinical drug trials
}

\author{
Subcommittee on Clinical Trials of the Chemotherapy of Leprosy \\ (THELEP) Scientific Working Group of the UNDP/World Bank/ \\ WHO Special Programme for Research and Training in Tropical \\ Diseases
}

\section{Accepted for publication 17 July 1996}

Summary During the period 1977-1983, clinical trials of five multidrug regimens were conducted among 215 patients with previously untreated multibacillary leprosy at the Institut Marchoux, Bamako, Mali, and the Central Leprosy Teaching and Research Institute, Chingleput, South India. The trials were designed primarily to permit measurement of the proportions of persisting Mycobacterium leprae in the patients' skin lesions. In addition, the combination of the large number of patients studied, the large volume of caref ully standardized data, and the employment of multidrug regimens provided a unique opportunity to measure the clinical response of patients to treatment by these regimens.

Persisting $M$. leprae were detected in $7 \cdot 8 \%$ of all specimens; the frequency did not vary with centre, regimen, or duration of treatment. The bacterial index (BI) decreased by a mean annual rate of $75 \%$, the logarithmic biopsy index by a mean annual rate of $87 \%$, and the $\operatorname{logarithm}_{10}$ number of acid-f ast bacilli per $\mathrm{g}$ tissue by a mean annual rate of $69 \%$. The rate of decrease of these measures of the numbers of $M$. leprae was related to the 'strength' of the regimen.

Although no difference of clinical status as a function of regimen was demonstrated, a difference was observed between the two centres, probably the result of different clinical criteria employed by the responsible physicians. A change of histopathological classification in the course of the trials was recorded for $12 \%$ of the patients, most representing upgrading from $\mathrm{LL}_{\mathrm{s}}$ to $\mathrm{BL}$, without relation to regimen or treatment centre.

ENL was less severe for the patients treated by the maximal regimen in Chingleput, which included daily clofazimine; as expected, the majority of patients treated by this regimen were found to have maximal pigmentation. Prednisolone was evidently preferred for treatment of ENL in Chingleput, whereas thalidomide was preferred in Bamako.

Fourteen cases of jaundice were observed, primarily among the patients treated by the maximal regimens, that included daily administration of rifampicin for the entire two years of the trials. Measurements of weight and blood pressure, and studies of the blood and of hepatic and urinary tract function revealed only negligible differences among regimens and between centres. In many cases, those differences that were observed were associated with ENL. 
Members of the THELEP Clinical Trials Subcommittee were:

Dr M. Christian,* Schieffelin Leprosy Research and Training Centre, Karigiri, South India,

Dr M. J. Colston, National Institute for Medical Research, London, UK,

Dr G. A. Ellard, National Institute for Medical Research, London, UK,

Dr C. A. P. Ferracci, ${ }^{*}$ Institute Marchoux, Bamako, Mali,

Dr J. H. Grosset, Faculte de Medicine Pitie-Salpetriere, Paris, France,

Dr G. Grossetete, Institut Marchoux, Bamako, Mali,

Dr C. G. S. Iyer,* Central Leprosy Teaching and Research Institute, Chingleput, South India,

Dr R. R. Jacobson, National Hansen's Disease Center, Carville, LA, USA,

Dr Ji Baohong, Faculte de Medicine Pitie-Salpetriere, Paris, France,

Dr Kyaw Lwin, Ministry of Health, Rangoon, Burma,

Dr D. L. Leiker, Royal Tropical Institute, Amsterdam, The Netherlands,

Dr L. Levy, Hebrew University-Hadassah Medical School, Jerusalem, Israel,

Dr S. K. Noordeen, World Health Organization, Geneva, Switzerland,

Dr S. R. Pattyn, Prince Leopold Institute for Tropical Medicine, Antwerp, Belgium,

Dr J. M. H. Pearson, Dhoolpet Leprosy Research Centre, Hyderabad, India,

Dr R. J. W. Rees, National Institute for Medical Research, London, UK,

Dr H. Sansarricq, World Health Organization, Geneva, Switzerland,

Dr P. S. Seshadri, Central Leprosy Teaching and Research Institute, Chingleput, South India,

Dr J. K. Seydel, Borstel Research Institute, Borstel, Federal Republic of Germany,

Dr C. C. Shepard, ${ }^{*}$ Centers for Disease Control, Atlanta, Georgia, USA,

Dr M. F. R. Waters, Hospital for Tropical Diseases, London, UK.

Also participating in this study were Mrs Pat Christie, Mrs Ila Mondavia, Miss Hilary Morgan, Mr Harry Shears and Mrs Maureen Silver, Laboratory for Leprosy and Mycobacterial Research, National Institute for Medical Research, London, UK; Dr A. C. McDougall, Slade Hospital, Oxford, UK; Dr M. N. Padma and Dr S. Balakrishnan, Central Leprosy Teaching and Research Institute, Chingleput, South India; and $\mathrm{Mr} \mathrm{H}$. Ouologuem, Institut Marchoux, Bamako, Mali. Mr J. L. Duppenthaler, World Health Organization, Geneva, Switzerland, provided statistical consultation throughout the trials, and Mrs M. Anker and Mr Y. Fushimi, World Health Organization, performed the statistical analyses.

This report was prepared by L. Levy, M. Anker and Y. Fushimi.

\section{Introduction}

During the period between August 1977 and the end of 1983, 215 patients with previously untreated multibacillary leprosy-99 at the Institut Marchoux, Bamako, Mali, and 116 at the Central Leprosy Teaching and Research Institute, Chingleput, South India-were recruited into clinical trials of treatment by one of five

* Deceased. 
regimens*. Treatment was continued for 2 years, in the course of which the patients were closely observed, and the results of numerous examinations recorded. The primary objective of the trials was the detection of persisting Mycobacterium leprae in the skin lesions of patients treated by different drug regimens. For this purpose, lesions were subjected to biopsy at intervals after the start of treatment, and $M$. leprae were recovered from the biopsy specimens and inoculated into the footpads of thymectomizedirradiated (TR) mice. In addition, the combination of the large number of patients studied, the large volume of carefully standardized data, and the employment of regimens of multidrug treatment (MDT) have provided a unique opportunity to measure the clinical response of patients to MDT.

\section{Materials and methods}

The patients recruited into the trials and many of the methods employed have already been described. ${ }^{1-8}$ In brief, patients with previously untreated multibacillary leprosy were assigned by random allocation to a treatment regimen. Before treatment was begun, the patients were carefully examined. Skin lesions were biopsied, and specimens were submitted for inoculation of mice, histopathological examination ${ }^{9}$ and measurement of the logarithmic biopsy index (LIB $)^{10}$; smears for measurement of the bacteriological index $(\mathrm{BI})^{11}$ were made from both ear lobules and four other standard sites; a nose-blow was obtained; and specimens of urine, faeces and blood were obtained for a variety of laboratory studies.

At intervals of 3,12 and 24 months after initiation of treatment by one of the trial regimens, skin-biopsy specimens were obtained and portions were air-shipped fresh on wet ice to the National Institute of Medical Research (NIMR), London. There, the largest possible number of $M$. leprae, but no more than $10^{5}$, were inoculated into each hind footpad of TR mice, usually 8 mice per specimen. About one year after inoculation, long enough for a single viable organism to have multiplied to a readily countable number, $M$. leprae were harvested from the hind footpads of all surviving mice and counted. Persisters-drug-susceptible $M$. leprae that survived antimicrobial treatment ${ }^{12}$ - were said to have been detected: if organisms had multiplied to at least $10^{6}$ in at least one footpad; or, in the event that the inoculum included fewer than $10^{5}$ organisms, if multiplication had occurred to a number at least 10 -fold the number inoculated, and to at least $10^{5}$ in at least one footpad; or if $M$. leprae multiplied in

\footnotetext{
* Patients were allocated among six treatment-groups, three in each centre; however, one of the five regimens (regimen $\mathrm{C}$ ) was employed in both centres. The regimens were in Bamako:

$\mathrm{A}_{2}$ : rif ampicin, prothionamide and dapsone, each in a daily dose of 600,500 , and $100 \mathrm{mg}$, respectively, for 2 years;

$\mathrm{C}_{\mathrm{B}}$ : rifampicin, in a single initial dose of $1500 \mathrm{mg}$, and dapsone, $100 \mathrm{mg}$ daily for 2 years;

$\mathrm{E}_{2}$ : rif ampicin, $900 \mathrm{mg}$ once weekly, and prothionamide, $500 \mathrm{mg}$ daily for the first 3 months, together with dapsone, $100 \mathrm{mg}$ daily for 2 years; and in Chingleput:

$\mathrm{A}_{1}$ : rif ampicin, clof azimine and dapsone, each in a daily dose of 600,100 , and $100 \mathrm{mg}$, respectively, for two years;

$\mathrm{C}_{\mathrm{C}}$ : as for Bamako; and

$\mathrm{D}_{1}$ : rifampicin, in a single initial dose of $1500 \mathrm{mg}$, clofazimine, in a daily dose of $100 \mathrm{mg}$ for the first 3 months, and dapsone, $100 \mathrm{mg}$ daily for 2 years ${ }^{1}$.
} 
passage. Portions of the biopsy specimens were also fixed and shipped to Oxford for histopathological examination and measurement of the LIB.

Every 4 weeks, patients were examined by the clinical investigator, who noted changes of the lesions, and questioned the patients with respect to symptoms suggesting adverse reactions to the drugs employed. In addition, specimens of urine and blood were obtained for laboratory study, and the occurrence of ENL and other leprosy reactions was recorded. In addition, at the first interval after the start of treatment, a nose-blow specimen was obtained.

Twelve weeks after the start of treatment, a formal clinical assessment was carried out, and a skin-lesion was biopsied, to provide specimens for both histopathological examination and inoculation of TR mice. Skin smears were made, and a nose-blow specimen was obtained. Beginning 24 weeks after the start of treatment, and every 24 weeks thereafter, skin smears were made, and specimens of urine and blood were obtained for laboratory study. Finally, after 12 and 24 months of treatment a formal clinical assessment was carried out.

The resulting data have been analysed by means of the ' $t$ '-test, and the techniques of $\chi^{2}$, exact probability, analysis of variance (ANOVA), and analysis of covariance. ${ }^{13}$

\section{Results}

As shown in Table 1, 215 patients were recruited -99 in Bamako and 116 in Chingleputand allocated in approximately equal numbers to the six regimens studied, with the exception of regimen $A_{2}$; the allocation of patients to regimen $A_{2}$ was stopped after only 12 patients had been assigned, because of a suspicion of hepatotoxicity, discussed below in detail. As shown in Table 1, 164 patients completed the trials, and an additional 16 patients were treated for at least one year but less than two years. There does not appear to be an association between regimen and failure to complete the trial. The results of the

Table 1. Numbers of patients and biopsy-specimens as a function of regimen

\begin{tabular}{lrrrrrr}
\hline & \multicolumn{5}{c}{ Regimen } \\
\cline { 2 - 6 } $\begin{array}{l}\text { Numbers of } \\
\text { specimens* }\end{array}$ & $\mathrm{A}_{2}$ & $\mathrm{C}_{\mathrm{B}}$ & $\mathrm{E}_{2}$ & $\mathrm{~A}_{1}$ & $\mathrm{C}_{\mathrm{C}}$ & $\mathrm{D}_{1}$ \\
\hline \multicolumn{7}{c}{ Numbers of patients } \\
4 & 7 & 37 & 32 & 34 & 31 & 33 \\
3 & 3 & 3 & 2 & 2 & 3 & 3 \\
2 & 1 & 3 & 2 & 3 & 4 & 0 \\
1 & 1 & 1 & 7 & 0 & 1 & 2 \\
Total & 12 & 44 & 43 & 39 & 39 & 38 \\
\hline
\end{tabular}

\footnotetext{
* Those patients who completed the trials are shown as having had four specimens examined for the presence of persisting $M$. leprae - a pretreatment specimen as well as specimens after 3, 12 and 24 months of treatment. In those cases in which only a single specimen was examined, the specimen was the pretreatment specimen; as a result, no specimens from these patients was examined for the presence of persisters.
} 
Table 2. Detection of persisting $M$. leprae as a function of centre, regimen, and duration of treatment

\begin{tabular}{|c|c|c|c|c|c|c|}
\hline \multirow[b]{2}{*}{ Variable } & \multicolumn{3}{|c|}{ Patients } & \multicolumn{3}{|c|}{ Specimens } \\
\hline & All & $\begin{array}{l}\text { Persisters } \\
\text { detected }\end{array}$ & $\begin{array}{c}\% \\
(95 \% \mathrm{CI})^{*}\end{array}$ & All & $\begin{array}{l}\text { Persisters } \\
\text { detected }\end{array}$ & $\begin{array}{c}\% \\
(95 \% \mathrm{CI})^{*}\end{array}$ \\
\hline \multicolumn{7}{|c|}{ Centre and regimen } \\
\hline Bamako & 90 & 18 & $\begin{array}{c}21 \cdot 1 \\
(13 \cdot 2-31 \cdot 0)\end{array}$ & 243 & 20 & $\begin{array}{c}8 \cdot 2 \\
(5 \cdot 1-12 \cdot 4)\end{array}$ \\
\hline $\mathrm{A}_{2}$ & 11 & 4 & $\begin{array}{c}36 \cdot 4 \\
(10 \cdot 9-69 \cdot 2)\end{array}$ & 27 & 4 & $\begin{array}{c}14 \cdot 8 \\
(4 \cdot 2-33 \cdot 7)\end{array}$ \\
\hline $\mathrm{C}_{\mathrm{B}}$ & 43 & 7 & $\begin{array}{c}16 \cdot 3 \\
(6 \cdot 8-30 \cdot 7)\end{array}$ & 119 & 8 & $\begin{array}{c}6 \cdot 7 \\
(3 \cdot 0-12 \cdot 8)\end{array}$ \\
\hline $\mathrm{E}_{2}$ & 36 & 7 & $\begin{array}{c}22 \cdot 2 \\
(10 \cdot 1-39 \cdot 2)\end{array}$ & 97 & 7 & $\begin{array}{c}8 \cdot 2 \\
(3 \cdot 6-15 \cdot 6)\end{array}$ \\
\hline Chingleput & 113 & 20 & $\begin{array}{c}17 \cdot 7 \\
(11 \cdot 2-26 \cdot 0)\end{array}$ & 311 & 23 & $\begin{array}{c}7 \cdot 4 \\
(4 \cdot 8-10 \cdot 9)\end{array}$ \\
\hline $\mathrm{A}_{1}$ & 39 & 5 & $\begin{array}{c}12 \cdot 8 \\
(4 \cdot 3-27 \cdot 4)\end{array}$ & 107 & 6 & $\begin{array}{c}5 \cdot 6 \\
(2 \cdot 1-11 \cdot 6)\end{array}$ \\
\hline $\mathrm{C}_{\mathrm{C}}$ & 38 & 8 & $\begin{array}{c}21 \cdot 0 \\
(9 \cdot 6-37 \cdot 3)\end{array}$ & 101 & 9 & $\begin{array}{c}8 \cdot 9 \\
(4 \cdot 2-16 \cdot 2)\end{array}$ \\
\hline$D_{1}$ & 36 & 7 & $\begin{array}{c}19 \cdot 4 \\
(8 \cdot 2-36 \cdot 0)\end{array}$ & 103 & 8 & $\begin{array}{c}7 \cdot 8 \\
(3 \cdot 4-14 \cdot 7)\end{array}$ \\
\hline \multicolumn{7}{|c|}{ Duration of treatment $\dagger$} \\
\hline 3 months & 201 & 17 & $\begin{array}{c}8 \cdot 5 \\
(5 \cdot 0-13 \cdot 2)\end{array}$ & & & \\
\hline 12 months & 185 & 18 & $\begin{array}{c}9 \cdot 7 \\
(5 \cdot 9-14 \cdot 9)\end{array}$ & & & \\
\hline 24 months & 168 & 8 & $\begin{array}{c}4 \cdot 8 \\
(2 \cdot 1-9 \cdot 2)\end{array}$ & & & \\
\hline $\begin{array}{l}3+12+24 \\
\text { months }\end{array}$ & 564 & $43 \ddagger$ & $\begin{array}{c}7 \cdot 8 \ddagger \\
(5 \cdot 7-10 \cdot 3)\end{array}$ & & & \\
\hline
\end{tabular}

The proportion of specimens in which persisters were detected did not differ significantly as a function of centre, regimen or duration of treatment.

$* 95 \%$ confidence interval.

$\dagger$ Because only one specimen was obtained from a patient at each interval during the trial, the numbers of patients are identical to the numbers of specimens.

$\ddagger$ Not significantly different from the corresponding values reported in the earlier paper, ${ }^{5}$ nor from the corrected values shown here for specimens reported by 31 December 1984.

clinical trials are further considered under two headings: therapeutic effects, and adverse effects.

\section{Therapeutic effects}

Detection of persisting M. leprae. This analysis includes results from the study of 554 specimens, representing 203 patients. No specimens were obtained from the remaining 12 patients, once treatment had been initiated, and the results from the study of 10 specimens, which yielded too few organisms to be counted, are excluded.

As shown in Table 2, persisting $M$. leprae were detected in 43 specimens, representing 38 patients. These numbers are not different from those presented in the preliminary report, ${ }^{5}$ which considered the 468 specimens, the study of which had been completed 
Table 3. Change of bacterial indices during treatment by THELEP regimens

\begin{tabular}{|c|c|c|c|c|c|c|c|}
\hline \multirow[b]{2}{*}{ Regimen } & \multicolumn{4}{|c|}{$\begin{array}{c}\text { Mean regression coefficient } \\
\text { (regression of variable on time) }\end{array}$} & \multicolumn{3}{|c|}{$\begin{array}{l}\text { Mean regression coefficient } \\
\text { (regression of first variable on second) }\end{array}$} \\
\hline & $\mathrm{BI}$ & LIB & LAFBPG & NB & $\mathrm{BI} / \mathrm{LIB}$ & BI/LAFBPG & LIB/LAFBPG \\
\hline \multicolumn{8}{|c|}{ Individual regimens } \\
\hline $\begin{array}{c}\text { Bamako } \\
\mathrm{A}_{2} \\
\mathrm{C}_{\mathrm{B}} \\
\mathrm{E}_{2}\end{array}$ & $\begin{array}{l}-0.57^{*} \\
-0.50 \\
-0.64\end{array}$ & $\begin{array}{l}-0 \cdot 70 \\
-1 \cdot 08 \\
-0.93\end{array}$ & $\begin{array}{l}-0.59 \\
-0.56 \\
-0.79\end{array}$ & $\begin{array}{l}-0.47 \\
-1.53 \\
-1.13\end{array}$ & $\begin{array}{l}0 \cdot 33 \\
0 \cdot 30 \\
0 \cdot 41\end{array}$ & $\begin{array}{l}0 \cdot 13 \\
0 \cdot 32 \\
0 \cdot 40\end{array}$ & $\begin{array}{l}0.38 \\
0.95 \\
0.54\end{array}$ \\
\hline $\begin{array}{l}\text { Chingleput } \\
\mathrm{A}_{1} \\
\mathrm{C}_{\mathrm{C}} \\
\mathrm{D}_{1} \\
\text { Mean } \\
p_{\text {individual }} \\
\text { Number of } \\
\text { observations }\end{array}$ & $\begin{array}{l}-0.64 \\
-0.44 \\
-0.65 \\
-0.57 \\
<0.006\end{array}$ & $\begin{array}{c}-1.35 \\
-0.75 \\
-0.98 \\
-0.89 \\
0.001\end{array}$ & $\begin{array}{l}-0.65 \\
-0.36 \\
-0.52 \\
-0.5 \\
0.026\end{array}$ & $\begin{array}{c}-0 \cdot 88 \\
-1 \cdot 10 \\
-1 \cdot 12 \\
-1 \cdot 10 \\
0 \cdot 180\end{array}$ & $\begin{array}{l}0.42 \\
0.38 \\
0.43 \\
0.37 \\
0.037\end{array}$ & $\begin{array}{l}0.61 \\
0.34 \\
0 \cdot 46 \\
0 \cdot 43 \\
0 \cdot 020\end{array}$ & $\begin{array}{l}1.08 \\
0.64 \\
0.85 \\
0 \cdot 84 \\
0.520\end{array}$ \\
\hline \multicolumn{8}{|c|}{ Combined regimens } \\
\hline $\begin{array}{l}\mathrm{A}_{2}+\mathrm{A}_{1} \\
\mathrm{C}_{\mathrm{B}}+\mathrm{C}_{\mathrm{C}} \\
\mathrm{E}_{2}+\mathrm{D}_{1} \\
p_{\text {combined }}\end{array}$ & $\begin{array}{l}-0.61 \\
-0.47 \\
-0.65 \\
<0.0001\end{array}$ & $\begin{array}{c}-1 \cdot 17 \\
-0.79 \\
-0.94 \\
0.018\end{array}$ & $\begin{array}{c}-0.64 \\
-0.46 \\
-0.64 \\
0.070\end{array}$ & $\begin{array}{c}-0.76 \\
-1 \cdot 33 \\
-1 \cdot 12 \\
0.085\end{array}$ & $\begin{array}{l}0 \cdot 4 \\
0 \cdot 32 \\
0 \cdot 45 \\
0 \cdot 016\end{array}$ & $\begin{array}{l}0 \cdot 48 \\
0 \cdot 34 \\
0 \cdot 45 \\
0 \cdot 190\end{array}$ & $\begin{array}{l}0 \cdot 83 \\
0 \cdot 82 \\
0 \cdot 71 \\
0.530\end{array}$ \\
\hline
\end{tabular}

Abbreviations: BI, bacteriological index; NB, BI of nose-blows; LIB, logarithmic biopsy index; LAFBPG, $\operatorname{logarith}_{10}$ of the number of AFB per $\mathrm{g}$ biopsy specimen; $p_{\text {individual, }}$, probability that the differences among the individual regimens occurred by chance; $p_{\text {combined, }}$ probability that the differences among the combined regimens occurred by chance.

* All the regression coefficients have been calculated on the basis of 365 days, except for those describing the changes of the BI of the nose-blows, which have been calculated on the basis of 90 days.

before 1 January 1985. In fact, among the 86 specimens, the study of which was completed after this date, persisting $M$. leprae were detected in only one-that obtained from patient 2059 after treatment for 12 months. This specimen is balanced by that obtained from patient 2051 after 3 months of treatment, which had been erroneously recorded as having yielded evidence of multiplication of $M$. leprae. Thus, persisting $M$. leprae were detected in $7 \cdot 8 \%$ of all specimens; and the frequency with which persisting $M$. leprae were detected could not be shown to vary with centre, regimen, or duration of treatment.

Bacteriological status. Changes during treatment of the BI of smears of skinscrapings and nose-blows, the logarithmic biopsy index (LIB), and the logarithm $_{10}$ of the number of $M$. leprae per $\mathrm{g}$ tissue (LAFBPG) ${ }^{3}$ are summarized in Table 3 . For these analyses, analysis of covariance was employed to test for differences among regimens of the mean change of the BI per unit time.

The BI decreased at the average rate of $0.571 \log _{10}$ units $(73 \%)$ per year. The data of Table 3 suggest that the BI decreased more slowly among the patients treated by regimen $\mathrm{C}$ in both Bamako and Chingleput, than was the case for the other regimens. This suggestion is confirmed by combining the data from both centres for regimen $\mathrm{C}$ (the 'minimal' regimen ${ }^{1}$ ), for regimens $A_{1}$ in Chingleput and $A_{2}$ in Bamako (the 'maximal' regimens ${ }^{1}$ ), and for regimens $D_{1}$ in Chingleput and $E_{2}$ in Bamako (the 'intermediate' 
regimens ${ }^{1}$ ). As shown in the lower half of the Table 3 , the rate of fall of the BI was significantly slower among the patients treated by regimen $C$ than among those treated by the other regimens. No relationship was found between primary resistance to dapsone $^{2}$ and the rate of fall of the BI. The LIB decreased with a mean annual rate of $0.894 \log _{10}$ units $(87 \%)$; as was the case for the BI, a relationship between the rate of decrease of the LIB and the 'strength' of the regimen is apparent. Finally, as is also shown in Table 3, the LAFBPG decreased during treatment, with a mean annual rate of $0.504 \log _{10}$ units $(69 \%)$, and the rate of decrease of the LAFBPG was slower for the patients treated by regimen $\mathrm{C}$ than for those treated by the remaining regimens. Thus, the numbers of organisms decreased more slowly during treatment by regimen $\mathrm{C}$ than during treatment by the other regimens; this was demonstrated more consistently in Chingleput than in Bamako.

The BI of nose-blows was initially higher among Bamako than among Chingleput patients. The median value for 72 Bamako patients was 3, whereas that for 111 Chingleput patients was $2(p<0.0001)$; in addition, only one Bamako patient failed to exhibit AFB in the pretreatment nose-blow specimen, whereas this was the case for 24 Chingleput patients $(p<0.0001)$ (the initial values had not been analysed in the paper ${ }^{3}$ describing the pretreatment characteristics of the patients). Perhaps as the result of the initially higher values, the nose-blows of fewer Bamako (17) than Chingleput patients (53) achieved a BI of 0 by the end of three months of treatment $(p<0.001)$. These initial differences between centres notwithstanding, the BI of nose-blows decreased at a mean rate of $1 \cdot 10 \log _{10}$ units $(92 \%)$ during the first 90 days of treatment, with no significant variation among regimens.

The BI, LIB and LAFBPG were found to be well correlated; all of the three possible correlation coefficients were greater than 0.5 , and the slopes of the regression of one variable on another were significantly greater than 0 in every case. The mean regression coefficients of LIB on LAFBPG did not differ significantly among regimens.

Clinical change. Clinical change during the course of the trials is considered in Table 4, in terms of clinical status, change of the proportion of skin visibly affected, change of the degree of skin-infiltration, and change of the size of the ulnar, median and lateral popliteal nerves. At the time of the formal clinical assessments, after treatment for three, 12 and 24 months, the patient's clinical status was assessed as 'definitely improved' ( score $=1)$, 'slightly improved' (score $=2)$, 'unchanged' (score $=3$ ), or 'deteriorated' $($ score $=4)$ since the last examination. The mean score was calculated for each patient, and the means were calculated for each regimen and centre. No difference of mean clinical status as a function of regimen was demonstrated by analysis of covariance. On the other hand, a significant difference was observed between the two centres; definite clinical improvement was recorded more frequently in Bamako than in Chingleput. Perhaps most important is that deterioration was reported in the case of only two patients, both of whom were treated by the minimal regimen in Bamako.

Also at the time of each formal clinical assessment, the proportion of skin visibly affected had been scored for each patient as $>75 \%$ (score $=3$ ), between 50 and $75 \%$ $($ score $=2)$, between 1 and $50 \%($ score $=1)$, or $<1 \%($ score $=0)$; the head, trunk, arms and legs were assessed separately, and scores for each portion of the body were summed. The change of the proportion of skin visibly affected was calculated for each patient by subtracting the latest from the first (pretreatment) value, and the mean values were subjected to analysis of covariance. Analysis of covariance showed that the mean 
Table 4. Clinical change during treatment by THELEP regimens

\begin{tabular}{lccccc}
\hline & \multicolumn{3}{c}{ Mean scores of: } & & $\begin{array}{c}\text { Histopathological change } \\
\text { Centre and } \\
\text { regimen }\end{array}$ \\
\cline { 2 - 5 } (proportion of patients)
\end{tabular}

Abbreviations: $\Delta$ Skin, change of the proportion of skin involved; $\Delta$ Infiltration, change of the degree of infiltration of the skin; $\Delta$ Size, change of the sizes of the peripheral nerves; $p_{\mathrm{B}}$, probability that the differences among the Bamako regimens occurred by chance; $p_{\mathrm{C}}$ probability that the differences among the Chingleput regimens occurred by chance; $p$, probability that the differences between treatment centres occurred by chance.

decrease of the proportion of affected skin varied according to regimen among Chingleput patients, being greater among those patients treated by regimens $C_{C}$ and $\mathrm{D}_{1}$ than among those treated by regimen $\mathrm{A}_{1}$, as may be noted in Table 4 . The mean decrease of the proportion of affected skin did not vary according to regimen among Bamako patients, and significantly more dramatic decreases of the proportion of affected skin were recorded in Bamako than in Chingleput.

In similar fashion, on the occasion of the formal clinical assessment, the degree of infiltration of the skin of the head, trunk, arms and legs had been assessed as 'marked' $($ score $=3)$, 'mild' (score $=2)$, 'macular' (score $=1)$, or 'none' (score $=0)$. The degree of infiltration was calculated for each patient, as was done for the proportion of skin visibly affected. Analysis of covariance indicated that the mean change of the degree of infiltration did not vary according to regimen. On the other hand, as may be noted in Table 4, significantly greater decreases of the degree of infiltration were recorded in Bamako than in Chingleput.

Also at the time of the formal clinical assessment, the sizes of both ulnar, median and lateral popliteal nerves were evaluated and recorded. Enlargement to greater than three times normal was given a score of 2 , enlargement to a lesser degree a score of 1 , and no enlargement a score of 0 . For each patient, the scores of all six nerves were summed, and the total at the time of the last examination was subtracted from that at the time of the first examination, yielding an expression of the change of nerve-size. Analysis of covariance indicated that the mean size of the nerves decreased among the patients treated by all three regimens in Bamako, and among those treated by only one of the three regimens in Chingleput, as shown in Table 4; decreases of nerve-size were recorded 
significantly more frequently among Bamako than among Chingleput patients. No significant variation according to regimen was shown for Bamako, whereas, in Chingleput, decreases of nerve-size was significantly greater among patients treated by regimen $D_{1}$ than among those treated by either of the two remaining regimens.

In addition to the proportion of skin involved, the degree of infiltration of the skin, and enlargement of the peripheral nerves, other assessments were made at the time of the periodic clinical examinations; these included erythema of the skin, nerve-pain and nerve-tenderness, disability of the hands and feet, and pathological changes of the eye. Because abnormalities had been noted initially in very small proportions of the patients in both treatment centres, improvement in the course of the trials could have occurred in the cases of only a very few of the patients; therefore, these data were not further analysed.

Histopathological change. As shown in Table 4, a change of histopathological classification in the course of the trials was recorded for $23(12 \%)$ of the 196 patients, for whom more than one specimen had been received in Oxford. Of the 23 changes of histopathological classification, 15 represented upgrading - in most cases a change from $\mathrm{LL}_{\mathrm{S}}$ to $\mathrm{BL}$, whereas 8 represented downgrading - half of them a change from $\mathrm{BL}$ to $\mathrm{LL}_{\mathrm{S}}$. Analysis by means of the $\chi^{2}$ statistic did not demonstrate a relationship of centre or regimen to these changes.

\section{Adverse effects}

$E N L$. In the course of the trials, the occurrence of ENL was recorded at monthly intervals; on these occasions, ENL was classified as absent $($ score $=0)$, mild (score $=1$ ) or severe (score $=2$ ), and the number of weeks during which the patient had demonstrated lesions of ENL was noted. In addition, the total quantities of prednisolone and thalidomide administered during the month were recorded. The data relating to ENL are summarized in Table 5. For the purpose of this analysis, an index of severity of ENL for each patient for the 2-year duration of the trials was constructed from three variables: SUMENL, the severity score $\times$ the number of weeks; SUMPRED, the total quantity of prednisone administered in the course of two years; and SUMTHAL, the total quantity of thalidomide administered. Analysis of these data suggests that ENL was less severe for the patients treated by regimen $\mathrm{A}_{1}$, and that prednisolone was preferred for treatment of ENL in Chingleput, whereas thalidomide was preferred in Bamako.

Pigmentation. At the time of the monthly clinical examination, patients were observed for evidence of the skin-pigmentation that characteristically occurs in the course of the prolonged administration of clofazimine. At these intervals, pigmentation was noted to be 'present and probably caused by clofazimine' (score $=3$ ), 'present but probably unrelated to clofazimine' (score $=2)$, or 'absent' (score $=1$ ). The numbers of Chingleput patients whose total pigmentation scores lay in the range $0-3,4-16$ or $19-24$ are shown in Table 6 (clofazimine was not a component of any of the regimens employed in Bamako). As expected, the majority of patients treated by regimen $A_{1}$ were found to have maximal scores, whereas all of the patients treated by regimen $C_{C}$, of which clofazimine was not a component, were observed to have no or minimal pigmentation; most of the patients treated by regimen $\mathrm{D}_{1}$ demonstrated intermediate scores. Analysis of these data by the $\chi^{2}$ statistic suggests that the likelihood that such a distribution could have resulted from chance was small indeed $\left(\chi^{2}=166_{\mathrm{df}=4} ; p<0 \cdot 0001\right)$. 
Table 5. ENL during treatment by THELEP regimens

\begin{tabular}{|c|c|c|c|c|c|}
\hline \multirow{2}{*}{$\begin{array}{l}\text { Centre and } \\
\text { regimen }\end{array}$} & \multicolumn{2}{|c|}{ Numbers of patients } & \multirow{2}{*}{$\begin{array}{c}\text { Mean } \\
\text { SUMENL* }\end{array}$} & \multirow{2}{*}{$\begin{array}{c}\text { Mean } \\
\text { SUMPRED }\end{array}$} & \multirow{2}{*}{$\begin{array}{c}\text { Mean } \\
\text { SUMTHAL }\end{array}$} \\
\hline & Total & With ENL & & & \\
\hline \multicolumn{6}{|l|}{ Bamako } \\
\hline $\mathrm{A}_{2}$ & 12 & 9 & $6 \cdot 1$ & 119 & 6550 \\
\hline $\mathrm{C}_{\mathrm{B}}$ & 44 & 23 & $6 \cdot 6$ & 112 & 6595 \\
\hline$E_{2}$ & 43 & 26 & $7 \cdot 1$ & 272 & 7271 \\
\hline$p_{\mathrm{B}}$ & & 0.34 & 0.45 & 0.45 & 0.67 \\
\hline \multicolumn{6}{|l|}{ Chingleput } \\
\hline $\mathrm{A}_{1}$ & 39 & 8 & $3 \cdot 2$ & 735 & 1183 \\
\hline $\mathrm{C}_{\mathrm{C}}$ & 39 & 23 & $17 \cdot 7$ & 1703 & 1844 \\
\hline $\mathrm{D}_{1}$ & 38 & 25 & $17 \cdot 2$ & 1744 & 3096 \\
\hline$p_{\mathrm{C}}$ & & 0.0001 & 0.0001 & 0.026 & $0 \cdot 10$ \\
\hline$p$ & & $0 \cdot 13$ & $0 \cdot 78$ & $0 \cdot 01$ & 0.0001 \\
\hline
\end{tabular}

Abbreviations: SUMENL, sum over the entire course of the trial of the monthly values of severity score $\times$ number of weeks during which ENL was present; SUMPRED, total quantity in $\mathrm{mg}$ of prednisolone administered; SUMTHAL, total quantity in $\mathrm{mg}$ of thalidomide administered; $p_{\mathrm{B}}$, probability that the differences among Bamako regimens occurred by chance; $p_{\mathrm{C}}$, probability that the differences among Chingleput regimens occurred by chance; $p$, probability that the differences between treatment centres occurred by chance.

* Numbers of patients demonstrating ENL of any degree of severity.

Changes of weight and blood-pressure. At the time of the monthly clinical examination, patients were weighed, and the arterial blood-pressure was measured by sphygmomanometry. As shown in Table 7, $31(27 \%)$ of 116 Chingleput patients and $8(8 \%)$ of 96 Bamako patients were found to have sustained weight-loss, defined as a loss of $>5 \mathrm{~kg}$ from the maximal weight recorded on more than one occasion during the trial, at some time during the course of treatment. Analysis by the $\chi^{2}$ statistic demonstrated no difference in terms of the frequency of weight-loss among regimens at each centre. Although fewer Bamako than Chingleput patients sustained weight-loss, many more measurements of weight were made in Chingleput (2444; $21 \cdot 1$ per patient) than in Bamako (633; 6.6 per patient); therefore, comparison of the frequency of weight-loss between centres may not be valid. It is also of interest that, according to the measurements of bodyweight made at the time patients were admitted to the trials, Bamako patients were considerably heavier than Chingleput patients $(57.8$ vs $44.8 \mathrm{~kg} ; p<0.0001)$ (this difference was not described in the earlier report ${ }^{3}$ ).

Table 6. Pigmentation of Chingleput patients as a function of regimen

\begin{tabular}{lrrr}
\hline & \multicolumn{3}{c}{ Pigmentation score } \\
\cline { 2 - 4 } Regimen & $0-3$ & $4-16$ & $19-24$ \\
\hline \multicolumn{4}{c}{ Number of patients } \\
$\mathrm{A}_{1}$ & 0 & 6 & 33 \\
$\mathrm{C}_{\mathrm{C}}$ & 39 & 0 & 0 \\
$\mathrm{D}_{1}$ & 7 & 31 & 0 \\
\hline
\end{tabular}


Table 7. Weight-loss and elevated blood-pressure as a function of treatment centre and regimen

\begin{tabular}{|c|c|c|c|c|c|c|}
\hline \multirow{2}{*}{$\begin{array}{l}\text { Centre and } \\
\text { regimen }\end{array}$} & \multirow[b]{2}{*}{ Total } & \multirow{2}{*}{$\begin{array}{l}\text { Weight- } \\
\text { loss* }\end{array}$} & \multicolumn{4}{|c|}{ Increase of blood-pressure } \\
\hline & & & $\mathrm{BP}_{\mathrm{S}}>140$ once & $\mathrm{BP}_{\mathrm{D}}>90$ once & $\mathrm{BP}_{\mathrm{S}}>140>$ once & $\mathrm{BP}_{\mathrm{D}}>90>$ once \\
\hline & \multicolumn{6}{|c|}{ Number of patients } \\
\hline \multicolumn{7}{|l|}{ Bamako } \\
\hline $\mathrm{A}_{2}$ & 12 & 0 & 1 & 0 & 1 & 0 \\
\hline $\mathrm{C}_{\mathrm{B}}$ & 42 & 5 & 10 & 2 & 6 & 1 \\
\hline$E_{2}$ & 42 & 3 & 7 & 0 & 6 & 0 \\
\hline All & & & & & & \\
\hline $\begin{array}{l}\text { regimens } \\
p_{\mathrm{B}}\end{array}$ & 96 & $\begin{array}{l}8 \\
0 \cdot 39\end{array}$ & $\begin{array}{l}18 \\
0 \cdot 43\end{array}$ & $\begin{array}{l}2 \\
0 \cdot 27\end{array}$ & $\begin{array}{l}13 \\
0 \cdot 85\end{array}$ & $\begin{array}{l}1 \\
0 \cdot 52\end{array}$ \\
\hline \multicolumn{7}{|l|}{ Chingleput } \\
\hline $\mathrm{A}_{1}$ & 39 & 8 & 3 & 4 & 2 & 0 \\
\hline $\mathrm{C}_{\mathrm{C}}$ & 39 & 11 & 3 & 5 & 1 & 1 \\
\hline $\mathrm{D}_{1}$ & 38 & 12 & 3 & 4 & 1 & 0 \\
\hline All & & & & & & \\
\hline regimens & 116 & 31 & 9 & 13 & 4 & 1 \\
\hline$p_{\mathrm{C}}$ & & 0.53 & $1 \cdot 0$ & 0.92 & 0.78 & $0 \cdot 37$ \\
\hline$p$ & & $0 \cdot 0008$ & 0.029 & $0 \cdot 016$ & $0 \cdot 014$ & $1 \cdot 0$ \\
\hline
\end{tabular}

Abbreviations: $\mathrm{BP}_{\mathrm{S}}$, systolic blood pressure; $\mathrm{BP}_{\mathrm{D}}$, diastolic blood pressure, $p_{\mathrm{B}}$, probability that the differences among the Bamako regimens occurred by chance; $p_{\mathrm{C}}$, probability that the differences among the Chingleput regimens occurred by chance; $p$, probability that the differences between treatment centres occurred by chance.

* Weight-loss is defined as a loss of $>5 \mathrm{~kg}$ from the maximal weight recorded on more than one occasion during the trial.

Although no differences were demonstrated among the regimens at each centre, elevations of the blood-pressure, both systolic and diastolic, were recorded more frequently in Bamako than in Chingleput, as is also shown in Table 7. These differences between centres are consistent with the fact that the initial measurements of blood pressure were higher in Bamako (mean 127/71) than in Chingleput (mean 106/68) $(p=0.0001)$ (this difference between centres was also not reported in the earlier paper $\left.{ }^{3}\right)$.

Adverse reactions and incidents. Evidence of adverse reactions was recorded at the time of the monthly clinical examination. In addition, adverse reactions and other incidents were recorded when they occurred. As shown in Table 8, with the exception of jaundice, few adverse reactions occurred; these were generally not serious, and were not thought to be related to the treatment. The cutaneous reactions, all of which were recorded in Chingleput, were two cases of erythema multiforme, one case of pruritus, and two rashes not otherwise described. Similarly, the abdominal reactions consisted, in Chingleput, of one case of nausea, and four of abdominal discomfort; in Bamako, six cases of nausea were recorded. The 'other' reactions, also all recorded in Chingleput, consisted of two cases of peripheral neuropathy, two of arthralgia, and one of fever.

The cases of jaundice, five in Bamako and nine in Chingleput, represent a potentially much more serious reaction; in fact, one of the two deaths recorded among patients treated by regimen $\mathrm{A}_{2}$ represented the culmination of an episode of jaundice. That four cases of jaundice, one resulting in death, occurred among the first 12 patients admitted to treatment by regimen $\mathrm{A}_{2}$ in Bamako stimulated the THELEP Steering Committee (SC) to suspect toxic hepatitis, and, until a review of the situation had been completed, to 
Table 8. Adverse reactions and related incidents as a function of centre and regimen

\begin{tabular}{|c|c|c|c|c|c|c|c|}
\hline \multirow{2}{*}{$\begin{array}{l}\text { Reaction or } \\
\text { incident }\end{array}$} & \multicolumn{3}{|c|}{ Bamako } & \multicolumn{3}{|c|}{ Chingleput } & \multirow[b]{2}{*}{$p^{*}$} \\
\hline & $\mathrm{A}_{2}$ & $\mathrm{C}_{\mathrm{B}}$ & $\mathrm{E}_{2}$ & $\mathrm{~A}_{1}$ & $\mathrm{C}_{\mathrm{C}}$ & $\mathrm{D}_{1}$ & \\
\hline & \multicolumn{7}{|c|}{ Number of patients } \\
\hline Adverse reactions & & & & & & & \\
\hline Skin & 0 & 0 & 0 & 2 & 2 & 1 & $0 \cdot 047$ \\
\hline Abdominal & 2 & 3 & 1 & 3 & 0 & 1 & $0 \cdot 33$ \\
\hline Jaundice & 4 & 0 & 1 & 5 & 2 & 2 & $0 \cdot 32$ \\
\hline Other & 0 & 0 & 0 & 2 & 0 & 3 & 0.047 \\
\hline All reactions & 6 & 3 & 2 & 12 & 4 & 7 & 0.07 \\
\hline \multicolumn{8}{|l|}{ Incidents } \\
\hline Removal & 6 & 5 & 11 & 7 & 8 & 7 & $0 \cdot 13$ \\
\hline Death & 2 & 0 & 1 & 0 & 1 & 1 & $0 \cdot 50$ \\
\hline \multicolumn{8}{|l|}{ Voluntary } \\
\hline withdrawal & 2 & 4 & 3 & 1 & 1 & 1 & 0.033 \\
\hline All incidents & 10 & 9 & 15 & 8 & 10 & 9 & 0.052 \\
\hline All patients & 12 & 42 & 42 & 39 & 39 & 38 & \\
\hline
\end{tabular}

${ }^{*} p$, probability that the differences between treatment centres occurred by chance.

suspend further recruitment into that regimen, and to stop the treatment by that regimen of patients who had already been recruited, but who had not completed 24 months' treatment. Although the review led to the conclusion that the jaundice had not resulted from toxic hepatitis, the SC decided not to resume admission of new patients to treatment by regimen $\mathrm{A}_{2}$; the rate at which new patients presented for admission into the trial had decreased to such a degree that the SC feared that resuming admission to treatment by regimen $\mathrm{A}_{2}$ would result in an insufficient number of patients having been treated by any regimen. The clinical investigators in Chingleput had concluded that the cases of jaundice did not represent toxic hepatitis. On the other hand, that jaundice occurred among nine of the 51 patients who had been treated by the maximal regimen in each centre and among only five of the 161 patients who had been treated by all of the other regimens suggests that those treated by the maximal regimens were at a significantly greater risk of jaundice $(p=0.0011)$. That jaundice occurred primarily among patients treated by the maximal regimens accounts for the significant difference among regimens of the frequency with which adverse reactions were noted.

Because patients suffering from adverse reactions to the prescribed treatment may withdraw from treatment prematurely, incidents - especially deaths, removal of patients from the trials, and voluntary withdrawal of the patients from the trials - are considered together with adverse reactions. That six of the 12 patients treated by regimen $A_{2}$ were removed from the trial in Bamako, reflecting the decision of the SC, and that two of the three deaths among Bamako patients occurred among patients treated by this regimen account for the differences of frequency of incidents among regimens. The frequency of incidents was not found to differ between centres, except for that of voluntary withdrawal.

Haematologic changes. Specimens of blood for haematologic examination were obtained by venipuncture at intervals in the course of the trials in Bamako and 
Table 9. Haematologic changes as a function of centre and regimen

\begin{tabular}{|c|c|c|c|c|c|c|c|c|c|}
\hline \multirow{2}{*}{$\begin{array}{l}\text { Centre and } \\
\text { regimen }\end{array}$} & \multirow{2}{*}{$\begin{array}{l}\text { Number of } \\
\text { patients or } \\
\text { observations }\end{array}$} & \multicolumn{2}{|c|}{ HCT } & \multicolumn{2}{|c|}{ WBC } & \multicolumn{2}{|c|}{ PMN } & \multicolumn{2}{|c|}{ PLAT } \\
\hline & & High* & Low & High & Low & High & Low & High & Low \\
\hline & & \multicolumn{8}{|c|}{ Number of patients } \\
\hline Bamako & & & & & & & & & \\
\hline $\mathrm{A}_{2}$ & 12 & 1 & 3 & 1 & 1 & 4 & 2 & 0 & 4 \\
\hline $\mathrm{C}_{\mathrm{B}}$ & 42 & 1 & 6 & 3 & 3 & 8 & 11 & 0 & 13 \\
\hline $\mathrm{E}_{2}$ & 42 & 1 & 6 & 4 & 3 & 6 & 12 & 0 & 13 \\
\hline Total & 96 & 3 & 15 & 8 & 7 & 18 & 25 & 0 & 30 \\
\hline$p_{\mathrm{B}}$ & & $0 \cdot 54$ & 0.63 & 0.92 & 0.99 & $0 \cdot 33$ & $0 \cdot 71$ & $1 \cdot 0$ & 0.99 \\
\hline \multicolumn{10}{|l|}{ Chingleput } \\
\hline $\mathrm{A}_{1}$ & 39 & 1 & 15 & 8 & 10 & 1 & 14 & 1 & 3 \\
\hline $\mathrm{C}_{\mathrm{C}}$ & 39 & 1 & 18 & 17 & 4 & 1 & 10 & 2 & 4 \\
\hline $\mathrm{D}_{1}$ & 38 & 1 & 20 & 24 & 6 & 4 & 11 & 2 & 4 \\
\hline Total & 116 & 3 & 53 & 49 & 20 & 6 & 35 & 5 & 11 \\
\hline$p_{\mathrm{C}}$ & & 1 & $0 \cdot 46$ & $0 \cdot 00075$ & $0 \cdot 19$ & $0 \cdot 19$ & $0 \cdot 60$ & $0 \cdot 80$ & $0 \cdot 90$ \\
\hline$p$ & & 1 & $<0.0001$ & $<0.0001$ & $0 \cdot 047$ & $0 \cdot 0036$ & $0 \cdot 61$ & 0.094 & 0.0001 \\
\hline \multicolumn{10}{|c|}{ Number of observations } \\
\hline Bamako & & & & & & & & & \\
\hline $\mathrm{A}_{2}$ & 92 & $\mathrm{NA}^{\dagger}$ & 6 & 1 & 1 & 5 & 3 & 0 & 4 \\
\hline $\mathrm{C}_{\mathrm{B}}$ & 315 & NA & 19 & 4 & 6 & 9 & 11 & 0 & 15 \\
\hline $\mathrm{E}_{2}$ & 278 & NA & 10 & 5 & 4 & 8 & 21 & 0 & 21 \\
\hline Total & 685 & NA & 35 & 10 & 11 & 22 & 35 & 0 & 40 \\
\hline$p_{\mathrm{B}}$ & & & $0 \cdot 33$ & 0.82 & $0 \cdot 83$ & 0.43 & 0.056 & $1 \cdot 0$ & $0 \cdot 28$ \\
\hline \multicolumn{10}{|l|}{ Chingleput } \\
\hline $\mathrm{A}_{1}$ & 830 & NA & 44 & 19 & 17 & 1 & 28 & 1 & 9 \\
\hline $\mathrm{C}_{\mathrm{C}}$ & 726 & NA & 32 & 36 & 4 & 2 & 26 & 11 & 4 \\
\hline $\mathrm{D}_{1}$ & 793 & NA & 58 & 54 & 6 & 5 & 23 & 6 & 5 \\
\hline Total & 2349 & NA & 134 & 109 & 27 & 8 & 77 & 18 & 18 \\
\hline$p_{\mathrm{C}}$ & & & 0.042 & $<0.0001$ & 0.0097 & $0 \cdot 20$ & $0 \cdot 74$ & 0.007 & $0 \cdot 42$ \\
\hline$p$ & & & $0 \cdot 56$ & $<0.0001$ & $0 \cdot 34$ & $<0.0001$ & 0.025 & 0.023 & $<0.0001$ \\
\hline
\end{tabular}

\footnotetext{
Abbreviations: HCT, hematocrit; WBC, number of white blood cells per $\mathrm{mm}^{3}$ peripheral blood; PMN polymorphonuclear leucocytes as per cent of WBC; PLAT, number of platelets per $\mathrm{mm}^{3}$ peripheral blood; $p_{\mathrm{B}}$, probability that the differences among Bamako regimens occurred by chance; $p_{\mathrm{C}}$, probability that the differences among Chingleput regimens occurred by chance; $p$, probability that the differences between treatment centres occurred by chance.

${ }^{*}$ High or low, with respect to the following criteria for each centre: HCT, Bamako and Chingleput: $>50 \%$ and $<30 \%$; WBC, Bamako: $\geq 12,000$ and $<4000$; Chingleput: $\geq 16,000$ and $<5000$; PMN, Bamako: $\geq 70 \%$ and $<20 \%$; Chingleput: $\geq 90 \%$ and $<40 \%$; PLAT, Bamako: $>400,000$ and $<200,000$; Chingleput: $>500,000$ and $<100,000$.

$\dagger$ NA, not analysed, because the cases of elevated HCT were too few.
}

Chingleput, and determinations of haematocrit (HCT), numbers of white blood cells (WBC) and blood platelets (PLAT) per $\mathrm{mm}^{3}$ of blood, and per cent of polymorphonuclear leukocytes (PMN) were performed at each centre. Because of the different frequencies with which these determinations were made in the two centres-approximately 20 per patient in Chingleput, and seven per patient in Bamako, these data have been analysed in terms of the numbers of both patients and observations, as summarized in Table 9. (The numbers of observations recorded per patient did not appear to be greater among those patients demonstrating abnormal values.) Three patients in each centre were each found on one occasion to have HCT $>50 \%$; except in one case, in which the HCT was $55 \%$, the values were 51 or $52 \%$. 
A large number of patients in both centres were found to have HCT $<30 \%$, many of these on more than one occasion. The frequency of low values of the HCT was significantly greater in Chingleput than in Bamako; however, the frequency did not vary among regimens. On the other hand, considering numbers of observations, the frequency of HCT $<30 \%$ did not differ between centres; in fact, although almost twice as many Chingleput as Bamako patients demonstrated HCT $<30 \%$, the proportion of observations demonstrating $\mathrm{HCT}<30 \%$ was virtually identical in both centres. The frequency of $\mathrm{HCT}<30 \%$ varied significantly among Chingleput regimens, but not among Bamako regimens, being greatest among the patients treated by regimen $D_{1}$, and least among those treated by regimen $\mathrm{A}_{1}$.

Considering both numbers of patients and numbers of observations, the frequency of elevated WBC was greater among Chingleput than among Bamako patients, despite the apparently more stringent criterion employed in Chingleput (see footnote to Table 9), a difference not accounted for by different numbers of observations. In addition, the frequency of elevated WBC was smaller among patients treated in Chingleput by regimen $A_{1}$ than among those treated by the remaining two regimens. Low values of the WBC were equally infrequent among Bamako and Chingleput patients, but, considering the numbers of observations, significantly more frequent among Chingleput patients treated by regimen $A_{1}$ than among those treated by regimens $C_{C}$ and $D_{1}$.

Considering numbers of both patients and observations, elevated values of PMN were more frequent among Bamako than among Chingleput patients. In fact, considering numbers of observations, the frequency of elevated values of PMN among Bamako patients was ten-fold that in Chingleput. The greater frequency of elevated values of PMN in Bamako appears to have resulted from the different criteria employed in the two centres (see footnote to Table 9); in fact, applying the less rigorous criterion $(\mathrm{PMN} \geq 70 \%)$ to the measurements in both centres yields a greater frequency of elevated PMN in Chingleput (16\% of observations) than in Bamako (3\% of observations). Considering numbers of patients, the frequency of low values of PMN did not differ significantly between the two centres; on the other hand, considering numbers of observations, low values of PMN were significantly more frequent among Bamako (5\% of observations) than among Chingleput (3\% of observations) patients, this despite the difference of criteria.

Elevated values of PLAT were not reported in Bamako, and were inf requent in Chingleput. Considering numbers of observations, elevated values of PLAT were less frequent among Chingleput patients treated by regimen $A_{1}$ than among those treated by the other two regimens. Although low values of PLAT appear to have been more frequent among Bamako than among Chingleput patients, this appears to have resulted from the employment in Chingleput of a more rigorous criterion (see footnote to Table 9). In fact, fully $10 \%$ of the values of PLAT among Chingleput patients were lower than $1.5 \times 10^{5}$ per ml, whereas fewer than $2 \%$ of values among Bamako patients were lower than this level. The frequency of low values of PLAT was not found to vary among regimens.

Changes of hepatic function. Specimens of blood for tests of hepatic function were also obtained at intervals during the clinical trials in Bamako and Chingleput, and measurements of serum bilirubin (SB), serum glutamic pyruvic transaminase activity (SGPT), and serum alkaline phosphatase activity (SAP) were performed. The results of these studies are summarized in Table 10. Elevations of SB were significantly more 
Table 10. Abnormal hepatic function tests as a function of centre and regimen

\begin{tabular}{|c|c|c|c|c|}
\hline \multirow{2}{*}{$\begin{array}{l}\text { Centre and } \\
\text { regimen }\end{array}$} & \multirow{2}{*}{$\begin{array}{l}\text { Number of patients } \\
\text { or observations }\end{array}$} & \multicolumn{3}{|c|}{ Elevations* of: } \\
\hline & & SB & SGPT & SAP \\
\hline & \multicolumn{4}{|c|}{ Number of patients } \\
\hline \multicolumn{5}{|l|}{ Bamako } \\
\hline $\mathrm{A}_{2}$ & 12 & 7 & 3 & 1 \\
\hline $\mathrm{C}_{\mathrm{B}}$ & 42 & 6 & 3 & 7 \\
\hline $\mathrm{E}_{2}$ & 42 & 6 & 8 & 6 \\
\hline Total & 96 & 19 & 14 & 14 \\
\hline$p_{\mathrm{B}}$ & & 0.0016 & $0 \cdot 17$ & 0.77 \\
\hline \multicolumn{5}{|l|}{ Chingleput } \\
\hline $\mathrm{A}_{1}$ & 39 & 7 & 12 & 10 \\
\hline $\mathrm{C}_{\mathrm{C}}$ & 39 & 10 & 17 & 12 \\
\hline $\mathrm{D}_{1}$ & 38 & 10 & 11 & 14 \\
\hline Total & 116 & 27 & 40 & 36 \\
\hline$p_{\mathrm{C}}$ & & $0 \cdot 62$ & $0 \cdot 33$ & 0.57 \\
\hline$p$ & & $0 \cdot 020$ & $0 \cdot 0014$ & 0.0074 \\
\hline \multicolumn{5}{|c|}{ Number of observations } \\
\hline Bamako & & & & \\
\hline $\mathrm{A}_{2}$ & 92 & 8 & 4 & 1 \\
\hline $\mathrm{C}_{\mathrm{B}}$ & 299 & 11 & 3 & 8 \\
\hline $\mathrm{E}_{2}$ & 271 & 6 & 15 & 6 \\
\hline Total & 662 & 25 & 22 & 15 \\
\hline$p_{\mathrm{B}}$ & & 0.019 & $0 \cdot 0089$ & 0.67 \\
\hline \multicolumn{5}{|l|}{ Chingleput } \\
\hline $\mathrm{A}_{1}$ & 829 & 8 & 18 & 24 \\
\hline $\mathrm{C}_{\mathrm{C}}$ & 770 & 25 & 58 & 32 \\
\hline $\mathrm{D}_{1}$ & 792 & 28 & 40 & 24 \\
\hline Total & 2391 & 61 & 116 & 80 \\
\hline$p_{\mathrm{C}}$ & & $0 \cdot 0015$ & $<0.0001$ & $0 \cdot 31$ \\
\hline$p$ & & 0.092 & 0.099 & $0 \cdot 16$ \\
\hline
\end{tabular}

Abbreviations: SB, serum bilirubin; SGPT, serum glutamic-pyruvic transaminase activity; SAP, serum alkaline phosphatase activity; $p_{\mathrm{B}}$, probability that the differences among the Bamako regimens occurred by chance; $p_{\mathrm{C}}$, probability that the differences among the Chingleput regimens occurred by chance; $p$, probability that the differences between treatment centres occurred by chance.

* Elevated with respect to the following criteria for each centre; SB, Bamako: $\geq 1.5 \mathrm{mg} \%$; Chingleput: $>1 \mathrm{mg} \%$; SGPT, Bamako and Chingleput: $>65 \mathrm{Karmen}$ units; SAP, Bamako: $>30 \mathrm{KA}$ units; Chingleput: $>20 \mathrm{KA}$ units.

frequent among Bamako than among Chingleput patients; this is almost entirely the result of the greater frequency of elevations of SB among Bamako patients treated by regimen $\mathrm{A}_{2}(p=0.0003)$. Among Chingleput patients, elevations of SB were significantly less frequent among patients treated by regimen $\mathrm{A}_{1}$.

Elevations of SGPT were significantly less frequent among Bamako than among Chingleput patients in terms of numbers of patients, but not in terms of numbers of observations. Considering numbers of observations, elevations of SGPT were significantly more frequent among Chingleput patients treated by regimen $\mathrm{C}$, but significantly less frequent among Bamako patients treated by this regimen. A larger proportion of Chingleput than of Bamako patients demonstrated elevated values of the SAP, probably reflecting the larger number of determinations performed in Chingleput. 
Table 11. Abnormalities of the urinary tract as a function of centre and regimen

\begin{tabular}{|c|c|c|c|c|c|}
\hline \multirow{2}{*}{$\begin{array}{l}\text { Centre and } \\
\text { regimen }\end{array}$} & \multirow{2}{*}{$\begin{array}{l}\text { Number of patients } \\
\text { or observations }\end{array}$} & \multirow{2}{*}{$\begin{array}{l}\text { Elevation of } \\
\text { the BUN* }\end{array}$} & \multirow{2}{*}{$\begin{array}{l}\text { Number of patients } \\
\text { or observations }\end{array}$} & \multicolumn{2}{|c|}{ Abnormal urinalysis } \\
\hline & & & & Once & $>$ once \\
\hline & \multicolumn{5}{|c|}{ Number of patients } \\
\hline \multicolumn{6}{|l|}{ Bamako } \\
\hline $\mathrm{A}_{2}$ & 12 & 3 & 12 & 2 & 4 \\
\hline $\mathrm{C}_{\mathrm{B}}$ & 42 & 2 & 42 & 9 & 10 \\
\hline $\mathrm{E}_{2}$ & 42 & 6 & 42 & 9 & 10 \\
\hline Total & 96 & 11 & 96 & 20 & 24 \\
\hline$p_{\mathrm{B}}$ & & $0 \cdot 11$ & & $0 \cdot 93$ & $0 \cdot 77$ \\
\hline \multicolumn{6}{|l|}{ Chingleput } \\
\hline $\mathrm{A}_{1}$ & 39 & 5 & 39 & 7 & 15 \\
\hline $\mathrm{C}_{\mathrm{C}}$ & 39 & 4 & 39 & 11 & 16 \\
\hline $\mathrm{D}_{1}$ & 38 & 6 & 38 & 7 & 20 \\
\hline Total & 116 & 15 & 116 & 25 & 51 \\
\hline$p_{\mathrm{C}}$ & & $0 \cdot 77$ & & 0.46 & 0.41 \\
\hline$p$ & & $0 \cdot 74$ & & $0 \cdot 88$ & 0.004 \\
\hline \multicolumn{6}{|c|}{ Number of observations } \\
\hline Bamako & & & & & \\
\hline $\mathrm{A}_{2}$ & 91 & 3 & 91 & - & 13 \\
\hline $\mathrm{C}_{\mathrm{B}}$ & 299 & 2 & 295 & - & 32 \\
\hline $\mathrm{E}_{2}$ & 270 & 7 & 275 & - & 35 \\
\hline Total & 660 & 12 & 661 & - & 80 \\
\hline$p_{\mathrm{B}}$ & & 0.12 & & - & 0.62 \\
\hline \multicolumn{6}{|l|}{ Chingleput } \\
\hline $\mathrm{A}_{1}$ & 830 & 6 & 845 & - & 82 \\
\hline $\mathrm{C}_{\mathrm{C}}$ & 792 & 4 & 799 & - & 81 \\
\hline $\mathrm{D}_{1}$ & 794 & 11 & 812 & - & 98 \\
\hline Total & 2416 & 21 & 2456 & - & 261 \\
\hline$p_{\mathrm{C}}$ & & $0 \cdot 15$ & & - & $0 \cdot 25$ \\
\hline$p$ & & 0.038 & & - & $0 \cdot 28$ \\
\hline
\end{tabular}

Abbreviations: BUN, blood urea nitrogen in $\mathrm{mg} \% ; p_{\mathrm{B}}$, probability that the differences among the Bamako regimens occurred by chance; $p_{\mathrm{C}}$, probability that the differences among the Chingleput regimens occurred by chance; $p$, probability that the differences between the centres occurred by chance.

* Elevated with respect to the following criteria for each centre: SB, Bamako: $\geq 40 \mathrm{mg} \%$; Chingleput: $>20 \mathrm{mg} \%$.

Changes of urinary tract function. The results of the measurements of blood urea nitrogen (BUN) and of the urinalyses are summarized in Table 11. As shown in Table 11, no differences among regimens were recognized. On the other hand, differences between the two treatment centres were evident. Although proportionately more measurements of the BUN were performed at Chingleput than at Bamako, and although the proportions of patients at each centre in whom elevations of the BUN were noted are similar, elevations of the BUN were recognized approximately twice as frequently at Bamako than at Chingleput. The situation with respect to abnormal urinalyses is the opposite. Approximately twice as many Chingleput patients as Bamako patients were noted to demonstrate abnormal urinalyses. However, this finding may be attributed to the greater number of urinalyses performed in Chingleput; approximately $10 \%$ of the urinalyses performed in Chingleput and $12 \%$ of those performed in Bamako were abnormal. 
Table 12. Relationships between ENL and weight-loss, elevated BP, hameatologic abnormalities, abnormalities of hepatic function, and urinary-tract abnormalities

\begin{tabular}{lcccc}
\hline & \multicolumn{4}{c}{ ENL } \\
\cline { 2 - 5 } Variable & Presence & $p^{*}$ & Severity & $p \dagger$ \\
\hline Weight-loss & $25 \%$ vs. $10 \%$ & 0.008 & $18.0 v s .7 .99$ & 0.0003 \\
Elevated BP & - & $>0.05$ & - & $>0.05$ \\
Reduced HCT & $39 \%$ vs. $25 \%$ & 0.047 & $18.5 v s .6 .00$ & 0.0001 \\
Elevated WBC & $36 \%$ vs. $17 \%$ & 0.002 & $21.0 v s .6 .00$ & 0.0001 \\
Elevated SB & - & $>0.05$ & - & $>0.05$ \\
Elevated SGPT & - & 0.02 & $15.7 v s .8 .10$ & 0.01 \\
Elevated SAP & $33 \% v s .15 \%$ & 0.002 & 14.1 vs. 8.70 & 0.04 \\
Elevated BUN & - & $>0.05$ & - & $>0.05$ \\
Abnormal urinalysis & - & $>0.05$ & $12.8 v s .6 .40$ & 0.003 \\
& & & & \\
\hline
\end{tabular}

\footnotetext{
* The statistical significance of these differences was examined by means of the $\chi^{2}$ test.

$\dagger$ The statistical significance of these differences was examined by means of a ' $t$ ' test.
}

Correlations among BP, weight-loss, voluntary withdrawal, and changes of haematologic status, hepatic function and urinary tract function with ENL. In the attempt to distinguish abnormalities resulting from adverse reactions to drugs from those resulting from other causes-especially ENL, relationships between ENL on the one hand and weight-loss, voluntary withdrawal, changes of haematologic status, and abnormalities of function of liver and urinary tract on the other, were sought. The results of this search are summarized in Table 12.

Weight-loss, defined as a loss of $>5 \mathrm{~kg}$ from the maximal weight recorded on more than one occasion during the trial, occurred with a significantly greater frequency among those patients demonstrating ENL of any degree of severity than among those without ENL. In addition, the ENL was found to be significantly more severe (the severity score was taken as the product of the severity recorded on each occasion and the number of weeks during which ENL was recorded) among those patients demonstrating weightloss than among those who did not. In addition, as is also shown in Table 12, ENL was found to be related to reduction of the HCT and to elevations of the WBC, SGPT and SAP. Severity of the ENL but not its mere presence was found to be related to an abnormal urinalysis.

On the other hand, although one might expect that those patients suffering from more severe ENL might be more likely to withdraw from the trial, no such relationship was found. Similarly, no relationship was demonstrated between elevation of the BP or an elevated SB and ENL.

\section{Discussion}

The primary objective of the analyses reported in this paper is the search for differences of therapeutic and adverse effects that might be attributed to the regimens employed in the trials. The therapeutic effects studied included the frequency with which persisting 
$M$. leprae were detected, change of the various measures (BI, LIB and LAFBPG) of the numbers of AFB harboured by the patients, and change of the patients' leprosy in terms of both clinical changes (clinical status, $\Delta$ Skin, $\Delta$ Infilt and $\Delta$ Size) and histopathological changes.

Among 554 specimens, representing 203 patients, persisting $M$. leprae were detected in only 43 specimens $(7 \cdot 8 \%$ of all specimens), representing 38 patients. As was reported earlier, ${ }^{5}$ the demonstration of persisting organisms appeared to be a random phenomenon, unrelated to regimen, centre or duration of treatment. It appears likely that, had a more sensitive means of detection been employed, such as, for example, the neonatally thymectomized rat, ${ }^{14}$ persisting organisms would have been demonstrated in a larger proportion of patients than was actually the case. The BI was found to decrease at the average rate of $0.571 \log _{10}$ units $(73 \%)$ per year, a rate slower than one of $90 \%$ per year, which is often assumed, but much like that reported earlier by Ridley. ${ }^{15}$ The LIB decreased with a mean annual rate of $0.894 \log _{10}$ units $(87 \%)$, and the LAFBPG with a mean annual rate of $0.504 \log _{10}$ units $(69 \%)$. The BI of nose-blows decreased by a mean of $1 \cdot 10 \log _{10}$ units $(92 \%)$ during the first 90 days of treatment. As expected, the BI LIB and LAFBPG were found to be well correlated. The numbers of AFB were found to decrease more slowly among the patients treated in both centres by regimen $\mathrm{C}$.

Clinical deterioration was reported in the case of only two patients, both of them treated in Bamako. The decrease of the proportion of skin involved was found to vary only in Chingleput; here, the decrease was least among the patients treated by the maximal regimen, regimen $A_{1}$. The decrease of mean nerve size also was found to vary only in Chingleput; the decrease was greater among the patients treated by regimen $\mathrm{D}_{1}$ than among those treated by either regimen $A_{1}$ or regimen $C_{C}$.

Change of histopathological classification in the course of the trials was recorded for $23(12 \%)$ of 196 patients, with no relationship to regimen or treatment centre. None of the remaining variables studied was found to differ among regimens. Thus, except for the slower rate of decrease of the number of AFB among the patients treated by regimen $\mathrm{C}$, no difference of therapeutic effect among the regimens was demonstrated. Given that the proportion of viable organisms did not differ among regimens, the significance of the difference among regimens of the total number of organisms, both viable and dead, is not clear.

Analysis of the measures of therapeutic effects by treatment centre reveals a few apparent differences. Bamako patients differed from those in Chingleput in several respects. Although the rate of fall of the BI of nose-blows during treatment did not differ between centres, the values observed before the start of treatment were larger in Bamako than in Chingleput, consistent with the larger pretreatment values of the BI measured from six skin sites in the former centre. ${ }^{3}$ Bamako patients weighed more on admission to the trial than did Chingleput patients, and elevated pretreatment values of the BP were recorded more frequently in Bamako. In addition to these differences among the patients of the two centres, differences of practice between the centres are apparent. Clinical improvement was recorded more frequently in Bamako than in Chingleput, and the decreases of $\Delta$ Skin, $\Delta$ Infilt and $\Delta$ Size were greater in Bamako.

Adverse effects were analysed in terms of ENL, pigmentation, changes of weight and $\mathrm{BP}$, adverse reactions-especially jaundice-and incidents, haematologic changes (HCT, WBC, PMN and PLAT), changes of hepatic function (SB, SGPT and SAP), and changes of urinary tract function (BUN and urinalysis). In addition, correlations 
with ENL were sought among BP, weight-loss, voluntary withdrawal, and changes of haematologic status, hepatic function and urinary tract function. In addition, other clinical assessments were made, including erythema of the skin, nerve-pain and nervetenderness, disability of the hands and feet, and pathological changes of the eye. Because abnormalities had been noted initially in very small proportions of the patients in both treatment centres, improvement in the course of the trials could have occurred in the cases of only a very few of the patients; therefore, these data were not further analysed.

A number of apparent differences among regimens were encountered. As might have been expected, ENL was less severe among those patients treated by regimen $A_{1}$ than among all of the remaining patients. Similarly, the degree of pigmentation was proportional to the dosage of clof azimine, being greatest among the patients treated by regimen $A_{1}$, and least among those treated by regimen $C_{C}$. Although the proportions of patients demonstrating low values of the HCT did not differ among regimens, analysis by number of observations shows a greater frequency among those patients treated by regimen $\mathrm{D}_{1}$ than among all of the remaining patients. Compared to the patients treated by all of the remaining regimens, both high and low values of the WBC were observed more frequently among the patients treated by regimen $A_{1}$, whereas elevations of PLAT and of SB were less frequent among these patients. Finally, elevations of SGPT were found more frequently among the patients treated by regimen $\mathrm{C}$ in Chingleput than among the corresponding patients in Bamako. The explanations of these differences are not immediately evident. That some of these differences may represent effects of ENL rather than of the regimen is considered below.

Analysis of adverse effects by treatment centre demonstrates that prednisolone was preferred for treatment of ENL in Chingleput, whereas thalidomide was preferred in Bamako. Because none of the regimens employed in Bamako included clofazimine, pigmentation by the drug was observed only in Chingleput. Several differences between the two centres appeared because observations were performed much more frequently in Chingleput than in Bamako; this was the case for weight-loss, abnormal values of the SGPT and SAP, and abnormal urinalyses. Finally, certain differences appear to reflect differences of criteria between the centres; such was the case for elevated values of PMN and low values of PLAT.

Perhaps not unexpectedly, certain of the adverse effects were associated with ENL, and may even be considered components of the ENL syndrome. Thus, ENL was found to be associated with weight-loss, reduced HCT, elevated WBC, elevations of the SGPT and SAP, and abnormal urinalyses. On the other hand, elevations of the BP and of the SB were not so associated, nor was there evidence that patients with ENL were more likely than those without to withdraw voluntarily from the trials.

Potentially the most important of the adverse effects is jaundice. Although the responsible clinicians, an expert consultant, and the members of the THELEP SC all came to the conclusion that jaundice among the trial patients did not represent an adverse reaction to a drug or drug-combination, it is perhaps of great importance that nine of the 14 cases occurred among patients treated by the maximal regimens in both treatment centres. Presumably, all 212 patients treated in both centres were more-or-less equally at risk of viral hepatitis and jaundice of other causes unrelated to the treatment prescribed. One wonders if the pref erence for daily rifampicin, as opposed to monthly administration of the drug, that has been so frequently expressed in discussions of 
multidrug regimens to be used in leprosy control, and currently the standard in the US ${ }^{16}$ should not be reconsidered.

\section{References}

1 Subcommittee on clinical trials of the Chemotherapy of Leprosy (THELEP) Scientific Working Group of the UNDP/World Bank/WHO Special Programme for Research and Training in Tropical Diseases. THELEP controlled clinical trials in lepromatous leprosy. Lepr Rev, 1983; 54: 167-76.

2 Subcommittee on clinical trials of the Chemotherapy of Leprosy (THELEP) Scientific Working Group of the UNDP/World Bank/WHO Special Programme for Research and Training in Tropical Diseases. Primary resistance to dapsone among untreated lepromatous patients in Bamako and Chingleput. Lepr Rev, 1983; 54: 177-83.

${ }^{3}$ Subcommittee on clinical trials of the Chemotherapy of Leprosy (THELEP) Scientific Working Group of the UNDP/World Bank/WHO Special Programme for Research and Training in Tropical Diseases. Characteristics of patients in the THELEP trials of chemotherapy of leprosy in Bamako and Chingleput. Le pr Rev, 1987; 58: 7-16.

4 Subcommittee on clinical trials of the Chemotherapy of Leprosy (THELEP) Scientific Working Group of the UNDP/World Bank/WHO Special Programme for Research and Training in Tropical Diseases. Primary dapsone-resistance in Bamako and Chingleput-final report. Lepr Rev, 1987; 58: 209-18.

5 Subcommittee on clinical trials of the Chemotherapy of Leprosy (THELEP) Scientific Working Group of the UNDP/World Bank/WHO Special Programme for Research and Training in Tropical Diseases. Persisting Mycobacterium leprae among THELEP trial patients in Bamako and Chingleput. Lepr Rev, 1987; 58: 325-37.

${ }^{6}$ Subcommittee on clinical trials of the Chemotherapy of Leprosy (THELEP) Scientific Working Group of the UNDP/World Bank/WHO Special Programme for Research and Training in Tropical Diseases. The THELEP controlled clinical drug trials. Int J Lepr, 1987; 55: 864-71.

7 Subcommittee on clinical trials of the Chemotherapy of Leprosy (THELEP) Scientific Working Group of the UNDP/World Bank/WHO Special Programme for Research and Training in Tropical Diseases. Characteristics of the multiplication of dapsone-resistant strains of Mycobacterium leprae in mice. Lepr Rev, 1988; 59: 5-10.

8 Standard Protocol for Chemotherapy Trials in Lepromatous Leprosy. World Health Organization Publication TDR/SWG-THELEP (1)/77.3, Annex 1, 1977.

9 Ridley DS, Jopling WH. Classification of leprosy according to immunity. A five-group system. Int J Lepr, 1966; 34: 255-73.

10 Ridley DS, Hilson GRF. A logarithmic index of bacilli in biopsies. Int J Lepr, 1967; 35: 184-6.

11 Ridley DS. Bacterial indices. In: Leprosy in theory and practice. Cochrane RG, Davey TF, (eds.) Williams \& Wilkins, Baltimore; 1964; pp 620-2.

12 Toman K. Bacterial persistence in leprosy. Int J Lepr, 1981; 49: 205-217.

13 Dixon WJ, Massey FJ. Introduction to statistical anal ysis, 3rd ed. McGraw-Hill Book Co., New York; 1969.

14 Gelber RH, Levy L. Detection of persisting Mycobacterium leprae by inoculation of the neonatally thymectomized rat. Int J Le pr, 1987; 55: 872-8.

15 Ridley DS. A logarithmic index of bacilli in biopsies. 2. Evaluation. Int J Lepr, 1967; 35: 187-93.

16 Jacobson RR. The face of Hansen's disease in the United States. Arch Dermatol, 1990; 126: 1627-30. 